\section{TWO EGYPTIAN GEESE SHOT IN SASKATCHEWAN}

by W. Harvey Beck, Saskatchewan Museum of

Natural History

In mid-November, 1964, two Egyptian Geese (Alopochen aegyptiacus) were shot one mile west of Alameda, Saskatchewan. Dr. G. D. Galloway of Oxbow was able to obtain from the hunter, before the birds were eaten, the head, a wing, some feathers from the back, and the feet of one of the birds which he submitted to the Museum for identification. The Egyptian Goose is a common bird of tropical and subtropical Africa-its range covering that continent except for the desert and deep forest areas. It has fairly long pink legs and a pink bill with black tip, margins, and base. The head and neck are pale grayish, mottled with brown on the sides and crown. There is a distinctive chestnut patch surrounding each eye, and a chestnut ring encircles the lower neck. The wing coverts are white, with a black line extending across the greater coverts; the primaries are black; the speculum is an iridescent metallic green; and the tertials are cinnamon.

The Museum has attempted to trace the source of the birds shot in Saskatchewan, and it appears likely that they were birds hatched in the 1963 season, from Devils Lake, North Dakota. Mr. Carl F. Smith, Superintendent of the School for the Deaf at Devils Lake, where Egyptian Geese are raised, wrote (March 16, 1965) that last fall "when the men were attempting to catch the birds to put them in winter housing, two Egyptian geese flew away and undoubtedly those are the two birds that were shot in Saskatchewan." Devils Lake is approximately 100 miles east of the Souris River. Because they are hardy birds with robust health, it is not unlikely that they, reportedly extremely strong flyers, managed to reach Saskatchewan. Normally the School for the Deaf personnel pinion their birds "by cutting off the tip of one wing. Evidently when the wings were cut on these two birds, they weren't cut short enough and grew out to full feather."

I would like to express thanks to the following individuals who assisted in tracking down the probable source of the Alameda birds: C. E. Strutz, Jamestown, N. Dak.; H. A. Stanton, Brandon, S. Dak.; C. F. Smith, Devils Lake, N. Dak.; and W. L. Kerr, PFRA Tree Nursery, Saskatoon.

\section{SECOND POOR-WILL SPECIMEN FOR SASKATCHEWAN}

by W. Harvey Beck, Saskatchewan Museum of Natural History

About 10 o'clock in the evening of July 15, 1964 a Poor-will (Phalaenoptilus nuttallii) was collected by Clive Elliott, then Student'Assistant with the Saskatchewan Museum of Natural History, while it was hawking for insects. The specimen (S.M.N.H. No. 8958) was taken at Calf Creek (8-822 w3), south of Klintonel, Saskatchewan, in the same general area where the first specimen for the province was collected on August 22, 1961 (Blue Jay, 19: 172).

\section{BIRD NOTES FROM URANIUM CITY}

Al Scarfe reports (letter, November 4,1964 ) seeing a flock of about 30 gulls, either Herring or California gulls, in late October at Bushell. His first fall observation of the Willow Ptarmigan, a bird in full winter plumage, on October 28, west of Fredette Lake is of interest. An earlier fall arrival date for the region is given as October 19, 1960 (Nero, R.W. 1963. Birds of the Lake Athabasca region, Saskatchewan. Spec. Pub. No. 5, S.N.H.S.). Incidentally, we were in error in saying in an Editor's Note (Blue Jay, $22: 126$ ) that ptarmigan had not been observed at Wollaston Lake in 1964; none was seen by our observers who went in on April 29, but they had been seen by residents during the winter, though in low numbers. A small flock of Snow Buntings seen between the middle and end of October is also noteworthy, but the female Downy Woodpecker seen at close range at the falls in town on Ootober 31 , is a rarity. Only a single previous record is noted in the "Birds of Lake Athabasca." 